\title{
New aspects in the diagnosis and treatment of primary spontaneous pneumothorax
}

\author{
Agata Dżeljilji ${ }^{1}$, Wojciech Rokicki ${ }^{2}$, Marek Rokicki $^{2}$, Krzysztof Karuś $^{3}$ \\ ${ }^{1}$ Department of Surgery, Institute of Tuberculosis and Lung Diseases, Warsaw, Poland \\ ${ }^{2}$ Department of Thoracic Surgery in Zabrze, Medical University of Silesia in Katowice, Poland \\ ${ }^{3}$ Center of Pulmonology and Thoracic Surgery, Bystra Śląska, Poland
}

Kardiochirurgia i Torakochirurgia Polska 2017; 14 (1): 27-31

\begin{abstract}
This paper provides a recapitulation of the position of the British Thoracic Society and the American College of Chest Physicians based on a review of the literature concerning the current methods of diagnosing and treating primary spontaneous pneumothorax (PSP). The previously developed guidelines were re-evaluated in 2015 by a task force of the European Respiratory Society (ERS). They are intended to be used by surgeons as well as emergency and pulmonary ward physicians, and they apply largely to emergency procedures. In recent years, the effectiveness of minimally invasive methods (punctures, drainage) in combination with talc pleurodesis for the initial therapy of PSP has been recognized. The efficacy of thoracoscopy (VATS) for the treatment of this disease has been proven by the development of minimally invasive surgical techniques in thoracic surgery. This paper also discusses the efficacy of the surgical methods available.

Key words: pneumothorax, British Thoracic Society (BTS).
\end{abstract}

\section{Introduction}

The symptoms of spontaneous pneumothorax, including dyspnea, cyanosis, and anxiety, were first described by Itard in 1803. In 1941, Tyson and Crandall proposed open thoracotomy with pleural abrasion as a treatment for this condition [1-4].

Primary spontaneous pneumothorax (PSP) is diagnosed when clinical methods of examination and the results of imaging diagnostics fail to establish the cause of the condition. In some patients, spontaneous pneumothorax is the first symptom of a developing disease. Difficulties with quickly establishing a correct diagnosis stem from the young age of the patients as well as the lack of characteristic symptoms, which is associated with the early stage of the disease. Differential diagnostics should also consider rare genetic disorders. Although the condition was first described over 200 years ago, its etiology remains elusive. The PSP is a significant clinical problem. Its yearly incidence

\section{Streszczenie}

Przedstawiona praca stanowi podsumowanie stanowiska British Thoracic Society (BTS) i American College of Chest Physicians (ACCP) na podstawie przeglądu piśmiennictwa dotyczącego aktualnych metod diagnostyki i leczenia samoistnej pierwotnej odmy opłucnowej (SPOO). W 2015 r. opracowane wytyczne zostały ponownie poddane ocenie przez Grupę Roboczą European Respiratory Society (ERS). Są przeznaczone zarówno dla chirurgów, jak i lekarzy izb przyjęć oraz oddziałów pulmonologicznych, dotyczą przede wszystkim postępowania doraźnego. W ostatnich latach podkreśla się skuteczność metod małoinwazyjnych (nakłucia, drenaże) w połączeniu z pleurodezą talkową w leczeniu początkowym SPOO. W związku z rozwojem małoinwazyjnych technik operacyjnych w chirurgii klatki piersiowej potwierdzono skuteczność torakoskopii (VATS) w terapii tego schorzenia. W niniejszym opracowaniu omówiono również skuteczność dostępnych metod operacyjnych.

Słowa kluczowe: odma opłucnowa, British Thoracic Society (BTS).

is estimated at 18-24 men/100 thousand and 6-9.8 women/100 thousand. The highest incidence (for both sexes) is observed among individuals aged $15-34$. In only $10 \%$ of patients diagnosed with PSP is an occurrence of the disease confirmed in the family medical history. The condition develops primarily in young, tall, slim men; over $80 \%$ are between the ages of 16 and 25. Pneumothorax is usually unilateral; the involvement of the right pleura is slightly more frequent. Simultaneous appearance of bilateral pneumothorax is observed in approximately $2 \%$ of patients. Higher incidence is observed in the warmer months - from May to October [5].

\section{Clinical symptoms}

A PSP incident may occur without any symptoms, or (depending on the size of the pneumothorax) it may be accompanied by sudden dyspnea, chest pain, elevated heart rate, anxiety, and increased hidrosis; intensification

Adddress for correspondence: Agata Dżeljilji MD, PhD, Department of Surgery, Institute of Tuberculosis and Lung Diseases, 26 Płocka St, 01-617 Warsaw, Poland, phone: +48 668376 010, e-mail: nosearmy85@gmail.com

Received: 22.01.2016, accepted: 14.10.2016. 
of these symptoms may lead to acute respiratory failure requiring immediate intervention. According to the guidelines of the British Thoracic Society (BTS) from 2003, approximately $50 \%$ of PSP patients seek medical attention more than 2 days after the appearance of symptoms [6]. No association has been proven between the occurrence of PSP and heavy physical exertion or strong emotions; in most cases, chest pain as a symptom of pneumothorax appeared while the patients were sleeping, walking, watching TV, or working on a computer.

\section{Diagnosis}

Accurate medical history, detailed physical examination, and evaluation of imaging examinations form the basis of establishing a PSP diagnosis. An X-ray image taken with the patient standing up (PA and lateral projections) has a sensitivity of approximately $70 \%$ in detecting the condition. In turn, computed tomography of the chest has a sensitivity of $100 \%$ and enables the physician not only to establish the size of the pneumothorax, but also to assess potential changes in the pulmonary parenchyma that may be the cause of the condition's occurrence [7].

\section{Management}

A trend toward the use of minimally invasive methods for the treatment of PSP can be observed in recent years $[8,9]$. The treatment provided to PSP patients is becoming increasingly conservative. This approach is considered safe as tension pneumothorax is rare in such patients (BTS 2010) [1]. A patient with a small pneumothorax, stable and without clinical symptoms, should be admitted to a hospital for 3-6 h of observation; if no progression is observed on control chest X-ray images, it is possible to discharge the patient home with the recommendation that they should urgently visit a hospital if dyspnea or chest pain appears. The remaining group of patients is constituted by individuals with pneumothoraces $>2 \mathrm{~cm}$ and developed clinical symptoms. Recommendations published by the American College of Chest Physicians (ACCP) permit the performance of pleural drainage (drain diameter $\leq 22 \mathrm{~F}$ ) as an effective method of initial treatment for PSP. The use of underwater drainage or the Heimlich valve is recommended in PSP patients. After a short period of observation and stabilizing the patient's condition, suction drainage may be introduced. Employing it too early increases the risk of pulmonary edema, particularly in patients with large pneumothoraces lasting for several days, in whom no attempt has been made to expand the lung. The risk of pulmonary edema in PSP patients may be as high as $14 \%$. In turn, the BTS recommends pleural aspiration as a treatment of choice for stable PSP. The authors of the European guidelines recommend thoracic aspiration in all PSP cases requiring intervention. Repeated needle aspirations are less effective in cases with a greater extent of lung collapse (>50\%) and in patients older than 50, which is associated with a higher probability of secondary spontaneous pneumothorax (SSP). Repeating needle aspiration is justified if the first attempt fails in an unstable patient in whom pneumothorax symptoms persist or if the first attempt results in the evacuation of no more than $2500 \mathrm{ml}$ of air (Fig. 1) [1]. Although chest drainage is the minimally invasive method preferred by many physicians, literature data do not confirm its greater efficacy in comparison with needle aspiration [10, 11].

In a randomized study conducted in France by Andrivet et al., the frequency of PSP recurrence after 3 months was $20 \%$ after needle aspiration and $28 \%$ after chest drainage [12]. Similar results were obtained by Harvey and Prescott in the United Kingdom after a follow-up of 12 months [13]. The results from the Belgian study by Noppen et al. confirm that, in the case of small pneumothoraces, aspiration is no less effective than invasive drainage (59\% vs. 63\%) [14]. The advantages of pleural aspiration as the initial treatment for PSP also include the reduction of pain and shorter hospitalization time.

It is worth noting that PSP patients are characterized by better tolerance of hypoxia than patients suffering from symptomatic spontaneous pneumothorax with concomitant pathology of the pulmonary parenchyma. Patients with dyspnea require quick action; regardless of the presence of concomitant diseases, an attempt should be made to expand the lung. In the case of coagulation disorders, thoracic aspiration is the preferred method. In the case of concomitant airway obstruction (asthma, allergy), pharmacological therapy should be introduced, and bronchofiberoscopy should be considered.

\section{Surgical treatment}

An important factor in the treatment of PSP is the fact that it is not a single nosological entity, but a symptom of an as yet unknown disease of the lungs or the pleura. All methods of surgical treatment for this condition are, therefore, symptomatic rather than causal. The lowest recurrence rates are observed after surgical treatment with pleurectomy and resection of the pulmonary parenchyma affected by emphysematous changes. Thanks to the created pleuropulmonary adhesions, any subsequent PSP incident involves a smaller extent of lung collapse and less severe clinical symptoms (it may even be asymptomatic). The BTS and ACCP guidelines for the treatment of PSP from 2010 list the following indications for surgical treatment: recurrent pneumothorax on the same side, pneumothorax recurrence on the opposite side, bilateral pneumothorax, persistent air leak (more than 5-7 days in a drainage system) or a failed attempt to expand the lung after minimally invasive treatment, hematoma of the pleural cavity, highrisk occupation (pilot, diver), and pregnancy. The binding recommendations do not discuss the selection of the surgical technique. Even in clinics of the same profile, the treatment methods vary with regard to:

1. Techniques used to create pleuropulmonary adhesions.

2. Extent of parietal pleurectomy.

3. Lung parenchyma resection. 


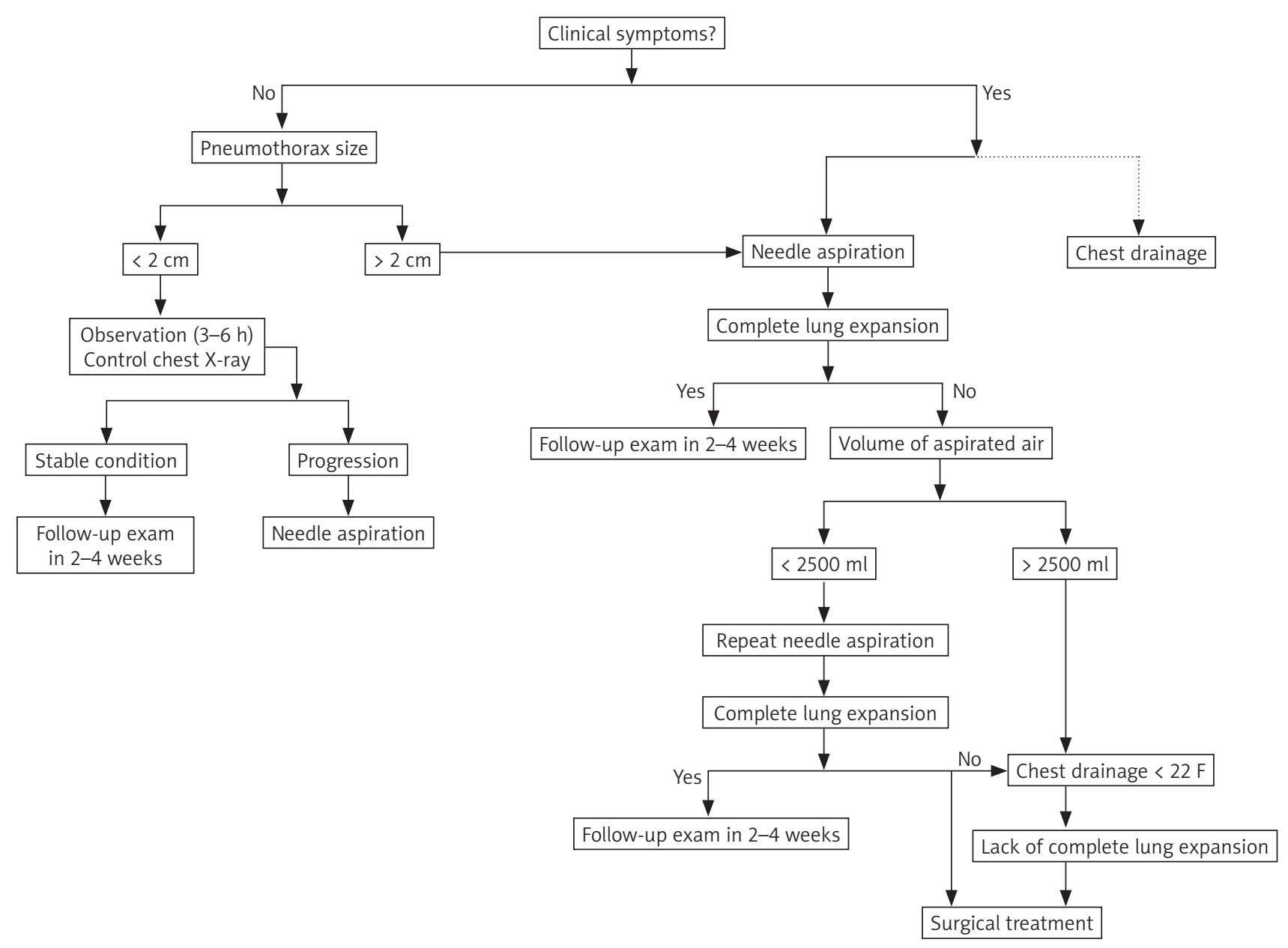

Fig. 1. Management of patients with primary spontaneous pneumothorax, modified in accordance with BTS guidelines

\section{Surgical access}

At present, video-assisted thoracoscopic surgery has become the "gold standard" of PSP treatment, as attested by numerous medical reports from all over the world [15]. Sedrakayan et al. published a meta-analysis comparing the results of surgical treatment for PSP in patients undergoing video-assisted thoracoscopic surgery (VATS) or minithoracotomy. The results demonstrated that the VATS technique is associated with shorter hospitalization, lower dosage of anesthetics, and similar rates of postoperative complications ranging from 0 to $16 \%$ [16]. A randomized study conducted by Freixinet et al., comparing VATS and axillary thoracotomy, found no statistically significant differences in postoperative blood loss, respiratory function, postoperative pain, dosage of anesthetics, duration of hospital stay, postoperative complications, or resumption of normal activity [17]. Additionally, Sawada et al. found no differences between the rates of pneumothorax recurrence associated with the two methods [18]. A different view was presented by Barker et al.; the researchers conducted a meta-analysis of 29 major reports (4 randomized and 25 non-randomized), comparing VATS with open surgery and observed that the recurrence rate associated with VATS was four times higher [19]. The observations of
Barker and Sedrakayan were not confirmed by Sekine et al., who reported that the outcomes of both treatment methods are similar, while noting that better postoperative values of spirometry and gas exchange parameters were achieved in patients undergoing VATS [20]. In summary, the advantages of the widely accepted VATS method undoubtedly include its low invasiveness and good cosmetic effects as well as the low and tolerable rate of PSP recurrence.

\section{Procedural technique}

Treatment efficacy is influenced by the techniques used to cause pleuropulmonary adhesions and perform the resection of the pulmonary parenchyma. Earlier experiences of surgeons performing open thoracotomy with parietal pleurectomy indicated that the method was highly effective and associated with low rates of pneumothorax recurrence [21-26]. Notwithstanding, later reports on the use of VATS presented satisfactory results for mechanical pleurodesis as well [27-29]. Studies on large groups of patients also demonstrated that combining bullectomy with chemical pleurodesis (talc) can reduce the recurrence rate to approximately 7\% [30], with mechanical pleurodesis (electrocoagulation, abrasion, laser) to 3.5\% [31, 32], and with pleurectomy to approximately $2 \%$ [33]. The reports in- 
dicate that both mechanical pleurodesis and parietal pleurectomy are highly effective. However, it should be noted that pleurectomy is associated with higher risk of bleeding and reoperation due to postoperative pleural hematomas.

In Europe, the most frequently used method for creating pleuropulmonary adhesions is talc pleurodesis. The method is safe and effective, and can be used to supplement chest drainage [34].

The extent of parietal pleurectomy is a matter of debate. Performing complete parietal pleurectomy is justified by the fact that emphysematous changes are not limited to the apical parts of the lungs. To a smaller degree they are also observed in the postero-apical area of the lower lobe; in rare cases, the changes can also be found in other peripheral parts of the pulmonary lobes. In patients with normal concentrations of $\alpha 1$-antitrypsin (A1AT), emphysematous changes are most often located in the upper parts of the lungs, which is associated with lower perfusion in the apical parts of the lungs and the consequent distribution of antiproteases in the lower areas. In turn, in patients with A1AT deficits, more pronounced changes develop in the lower parts of the lungs, which stems from the higher concentration of neutrophils supplied with blood [35]. Replacing parietal pleurectomy or pleural abrasion extending from the apex to the costodiaphragmatic recess with partial procedures limited to the apex of the chest is associated with higher rates of recurrence on the one hand, but lower incidence of postoperative complications on the other [36-38]. Currently, most surgeons remove emphysematous bullae larger than 2-3 cm using endostaplers, while smaller bullae are obliterated with electrocoagulation. There is no consensus on whether apical lung resection should be performed routinely. Considering the abovementioned observations that emphysematous changes are most frequently located in the pulmonary apex, routine resection of the apex with a stapler seems acceptable, although there is no evidence attesting to the efficacy of such treatment. Regrowth of emphysematous bullae along the staple line is believed to be one of the causes of recurrence after surgical treatment. Sakamoto et al. proposed a method consisting in covering the staple line with an additional absorbable continuous suture. Their observations, however, pertained to short-term results. In the group of patients treated in this manner, no persistent air leaks (PAL) were observed during the postoperative period. The results were compared with those of the control group, where the incidence of PAL was almost 5\%. The study included both PSP and SSP patients [39]. Literature reports on the effectiveness of particular treatment methods very often discuss spontaneous pneumothorax as a single entity, without distinguishing whether it is primary or secondary. In our view, this impedes comparison of treatment results. However, we decided to mention Sakamoto's research because it pertains to the safety of bullectomy. The complete lack of postoperative PAL in SSP patients seems particularly interesting, as the incidence of postoperative PAL in this patient group may be as high as $20 \%$.

\section{Conclusions}

The published recommendations come in the form of suggestions rather than strict guidelines. The decision whether an attempt to expand the lung is required is based primarily on the presence and intensity of clinical symptoms and, to a lesser degree, on the size of the pneumothorax.

In stable patients without clinical symptoms, the management can be limited to observation. In the remaining cases, the initial treatment should include needle aspiration, although chest drainage is also acceptable. The published guidelines on short-term management enable the provision of care to PSP patients not only in surgical wards, but also in emergency rooms and pulmonary wards, which reduces the cost of therapy. Recent years have seen a trend toward minimally invasive surgical methods for the treatment of PSP. There is a complete consensus on the choice of surgical access: VATS is now the gold standard. The choice of the surgical technique should aim to minimize complications and recurrence. It is also worth noting that PSP treatment should not end with the surgical procedure; the patients should remain under the supervision of a pulmonary center. Further monitoring should provide more diagnostic data and improve the knowledge about the progression of this condition.

\section{Disclosure}

Authors report no conflict of interest.

\section{References}

1. MacDuff A, Arnold A, Harvey J; BTS Pleural Disease Guideline Group. Management of spontaneous pneumothorax: British Thoracic Society pleural disease guideline 2010. Thorax 2010; 65 Suppl 2: ii18-ii31.

2. Baumann MH, Strange C, Heffner JE, Light R, Kirby TJ, Klein J, Luketich JD, Panacek EA, Sahn SA; AACP Pneumothorax Consensus Group. Management of spontaneous pneumothorax: an American College of Chest Physicians Delphi consensus statement. Chest 2001; 119: 590-602.

3. Tschopp JM, Bintcliffe O, Astoul P, Canalis E, Driesen P, Janssen J, Krasnik M, Maskell N, Van Schil P, Tonia T, Waller DA, Marquette CH, Cardillo G. ERS task force statement: diagnosis and treatment of primary spontaneous pneumothorax. Eur Respir J 2015; 46: 321-335.

4. Tyson MD, Crandall WB. The surgical treatment of recurrent idiopatic spontaneous pneumothorax. J Thorac Surg 1941; 10: 566-570.

5. Pereira Silva R, Vicente I, Magalhaes E, Valente MJ, Valente M la Salente. Is the incidence of spontaneous pneumothorax associated with climacteric conditions? Eur Respir J 2016; 48: PA4257.

6. Henry A, Arnold T, Harvey J. BTS guidelines for the management of spontaneous pneumothorax. Thorax 2003; 58 Suppl 2: ii39-ii52.

7. Lesur O, Delorme N, Fromaget JM, Bernadac P, Polu JM. Computed tomography in the aetiological assessment of idiopathic spontaneous pneumothorax. Chest 1990; 98: 341-347.

8. Kaneda H, Nakano T, Taniguchi Y, Saito T, Konobu T, Saito Y. Three-step management of pneumothorax: time for a re-think on initial management. Interact Cardiovasc Thorac Surg 2013; 16: 186-192.

9. Brims FJ, Maskell NA. Ambulatory treatment in the management of pneumothorax: a systematic review of the literature. Thorax 2013; 68: 664-669.

10. Parlak M, Uil SM, van den Berg JW. A prospective, randomised trial of pneumothorax therapy: manual aspiration versus conventional chest tube drainage. Respir Med 2012; 106: 1600-1605.

11. Ayed AK, Chandrasekaran C, Sukumar M. Aspiration versus tube drainage in primary spontaneous pneumothorax: a randomised study. Eur Respir J 2006; 27: 477-482. 
12. Andrivet P, Djedaini K, Teboul JL, Brochard L, Dreyfuss D. Spontaneous pneumothorax: comparison of thoracic drainage vs. immediate or delayed needle aspiration. Chest 1995; 108: 335-339.

13. Harvey J, Prescott RJ. Simple aspiration versus intercostal tube drainage for spontaneous pneumothorax in patients with normal lungs. BMJ 1994; 309: 1338-1339.

14. Noppen M, Alexander P, Driesen P, Slabbynck H, Verstraeten A. Manual aspiration versus chest tube drainage in first episodes of primary spontaneous pneumothorax. Am J Respir Crit Care Med 2002; 165: 1240-1244.

15. Vohra HA, Adamson L, Weeden DF. Does video-assisted thoracoscopic pleurectomy result in better outcomes than open pleurectomy for primary spontaneous pneumothorax? Interact Cardiovasc Thorac Surg 2008; 7: 673-677.

16. Sedrakayan A, van der Meulen J, Lewsey T, Treasure T. Video assisted thoracic surgery for treatment of pneumothorax and lung resections: systematic review of randomised clinical trials. Br Med J 2004; 329: 1008.

17. Freixinet JL, Canalís E, Juliá G, Rodriguez P, Santana N, Rodriguez de Castro F. Axillary thoracotomy versus videothoracoscopy for the treatment of primary spontaneous pneumothorax. Ann Thorac Surg 2004; 78: 417-420.

18. Sawada S, Watanabe $Y$, Moriyama S. Video-assisted thoracoscopic surgery for primary spontaneous pneumothorax: evaluation of indications and longterm outcome compared with conservative treatment and open thoracotomy. Chest 2005; 127: 2226-2230.

19. Barker A, Maratos EC, Edmonds L, Lim E. Recurrence rates of video assisted thoracoscopic versus open surgery in the prevention of recurrent pneumothoraces: a systematic review of randomised and nonrandomised trials. Lancet 2007; 370: 329-335.

20. Sekine Y, Miyata Y, Yamada K, Yamada H, Yasukawa T, Saitoh Y, Yoshida S, Fujisawa T. Video-assisted thoracoscopic surgery does not deteriorate postoperative pulmonary gas exchange in spontaneous pneumothorax patients. Eur J Cardiothorac Surg 1999; 16: 48-53.

21. Efdeldt RJ, Schroeder D, Meinicke O. Spontaneus pneumothorax: Uberlegun gen zur Atiologie und Therapie. Chirurg 1991; 62: 540-546.

22. Baronofsky ID, Warden HG, Kaufman JL, Whatley J, Hanner JM. Bilatera therapy for unilateral spontaneous pneumothorax. J Thorac Cardiovasc Surg 1957; 34: 1767-1769.

23. Gobel WG, Rhea WG, Nelson IA, Daniel RA. Spontaneus pneumothorax. J Thorac Cardiovasc Surg 1963; 46: 331-345.

24. Askew AR. Parietal pleurectomy for recurrent pneumothorax. Br J Surg 1976; 63: 203-205.

25. Weeden D, Smith GH. Surgical experience in the management of spontaneous pneumothorax, 1972-1982. Thorax 1988; 38: 737-743.
26. van de Brekel JA, Duurkens VAM, Vanderschueren RGJRA. Pneumothorax: results of thoracoscopy and pleurodesis with talc pudrage and thoracotomy. Chest 1993; 103: 345-347.

27. Liu HP, Lin PJ, Hsieh MJ, Chang JP, Chang CH. Thoracoscopic surgery as a routine procedure for spontaneous pneumothorax: results from 82 patients. Chest 1995; 107: 559-562.

28. Naunheim KS, Mack MJ, Hazelrigg SR, Ferguson MK, Ferson PF, Boley TM, Landreneau RJ. Safety and efficacy of video assisted thoracic surgical techniques for the treatment of spontaneous pneumothorax. J Thorac Cardiovasc Surg 1995; 109: 1198-1203.

29. Huertgen M, Buhr J, Kluth D. Thoracoskopische Operation des sekundaren Spontanpneumothorax. Chirurg 1995; 66: 994-996.

30. Boutin C, Viallat JR, Aelony Y. Practical Thoracoscopy. Springer, Heidelberg, 1991

31. Gossot D, Galetta D, Stern JB, Debrosse D, Caliandro R, Girard P, Grunenwald D. Results of thoracoscopic pleural abrasion for primary spontaneous pneumothorax. Surg Endosc 2004; 18: 466-471.

32. Lang-Lazdunski L, Chapuis O, Bonnet PM, Pons F, Jancovici R. Videothoracoscopic bleb excision and pleural abrasion for the treatment of primary spontaneous pneumothorax: long-term results. Ann Thorac Surg 2003; 75: 960-965.

33. Ayed AK. Suction versus water seal after thoracoscopy for primary spontaneous pneumothorax: prospective randomized study. Ann Thorac Surg 2003; 75: 1593-1596.

34. Bridevaux PO, Tschopp JM, Cardillo G, Marquette CH, Noppen M, Astoul P, Driesen P, Bolliger CT, Froudarakis ME, Janssen JP. Short-term safety of thoracoscopic talc pleurodesis for recurrent primary spontaneous pneumothorax a prospective European multicentre study. Eur Respir J 2011; 38: 770-773.

35. Tomashefski J Jr, Cagle P, Farver C, Fraire A. Dail and Hammar's Pulmonary Pathology. Vol. I, Nonneoplastic Lung Disease. Third edition. Springer, New York 2008.

36. Light RW. Management of spontaneous pneumothorax. Am Rev Respir Dis 1993; 148: 245-8.

37. Maggi G, Ardissone F, Oliaro A, Ruffini E, Cianci R. Pleural abrasion in the treatment of recurrent or persistent spontaneous pneumothorax. Result of 94 consecutive cases. Int Surg 1992; 77: 99-101.

38. De Leyn P, Lismonde M, Ninane V, Noppen M, Slabbynck H, Van Meerhaeghe A, Van Schil P, Vermassen F. Belgian Society of Pneumology: guidelines on the management of spontaneous pneumothorax. Acta Chir Belg 2005; 105: 265-267.

39. Sakamoto K, Takei H, Nishii T, Maehara T, Omori T, Tajiri M, Imada T, Takanashi Y. Staple line coverage with absorbable mesh after thoracosopic bullectomy for spontaneous pneumothorax. Surg Endosc 2004; 18: 478-481. 